\title{
MUSIK TRUNTHUNG SEBAGAI WUJUD KEARIFAN LOKAL DALAM KONTEKS PENDIDIKAN SENI
}

\author{
Fajry Sub'haan Syah Sinaga \\ Jurusan Sendratasik, Fakultas Bahasa dan Seni, Universitas Negeri Padang \\ fajry.sinaga@fbs.unp.ac.id
}

\begin{abstract}
Abstrak
Pengaruh globalisasi saat ini memberikan banyak sekali ruang yang berdampak pada diversitas budaya. Penguatan identitas budaya menjadi modal utama untuk memperkuat jati diri bangsa, tidak terkecuali dalam ranah pendidikan seni. Konten budaya dan tradisi menjadi sumber utama penerapan kearifan lokal baik dalam dimensi logis, estetis, maupun etis. Artikel ini memberikan gambaran bahwa musik Trunthung merupakan salah satu wujud kearifan lokal yang ada di Dusun Warangan yang berimplikasi pada proses penguatan identitas bangsa dalam konteks pendidikan seni.
\end{abstract}

Kata kunci: identitas bangsa; kearifan lokal; pendidikan seni; trunthung

\begin{abstract}
The influence of globalization now gives a lot of space that has an impact on cultural diversity. Strengthening cultural identity becomes the main capital to strengthen national identity, not least in the realm of art education. Cultural content and tradition become the main source of the application of local wisdom in both logical, aesthetic, and ethical dimensions. This article illustrates that Trunthung music is a form of local wisdom in Warangan Hamlet which has implications for the process of strengthening the nation's identity in the context of art education.
\end{abstract}

Keywords: national identity; local wisdom; art education; trunthung

\section{Pendahuluan}

Indonesia merupakan sebuah negara yang dilalui garis khatulistiwa dan terletak diantara dua benua yaitu Benua Asia dan Benua Australia, selain itu juga terdapat dua samudera yang mengapit Indonesia yaitu Samudera Hindia dan Samudera Pasifik. Karena faktor alam tersebut tidak heran jika Indonesia menjadi negara kepulauan yang memiliki beragam corak kebudayaan, suku, dan bahasa. Selain faktor alam yang dimiliki, keberagaman tersebut semakin bercorak dengan kedatangan para pedagang-pedagang asing di masa lampau yang datang dari Asia dan Eropa, hal ini menjadikan pemahaman secara pragmatis bahwa besar kemungkinan adanya perubahan sosial yang terjadi baik secara paksa maupun adanya kemauan dari masyarakat Indonesia yang menerima budaya lain.

Diversitas budaya yang terjadi karena pengaruh globalisasi memberikan dampak yang cukup signifikan kepada manifestasi budaya pada saat ini (Sukarwo, 2017, p. 311). Salah satu wujud penguatan identitas budaya adalah dengan terus mengembangkan kesenian tradisional yang memuat begitu banyak falsafah dan pranata sosial. Manifestasi 
tersebut sering dikenal dengan nama kearifan lokal. Salah satu manifestasi kearifan lokal di Dusun Warangan Kabupaten Magelang adalah hadirnya musik Trunthung sebagai produk seni yang menjadi kebanggan tersendiri bagi masyarakat Warangan.

Musik Trunthung muncul pertama kali tahun 2002 di Dusun Warangan, Kecamatan Pakis, Kabupaten Magelang yang dipelopori oleh Eko Sunyoto dan Sutanto Mendut. Mereka berdua menggarap Trunthung untuk pertama kali menjadi sebuah sajian pertunjukan kolosal yang dimainkan oleh 80 orang ketika mengikuti gelar nasional dan pembukaan Galeri Langgeng Kabupaten Magelang (Sinaga, 2016). Seiring perjalanan waktu, musik Trunthung menjadi bagian yang turut serta berkontribusi dalam hal penguatan identitas bangsa sebagai wujud kearifan lokal dari lereng Merbabu (Indonesia, n.d.). Pada artikel ini penulis ingin melihat Musik Trunthung dalam perpektif pendidikan seni yang terbagi menjadi dua kegiatan yaitu kreatif dan apresiatif dalam ruang budaya.

\section{Metode Penelitian}

Penulisan artikel ini diawali dengan penelitian pada tahun 2016 tentang perubahan musik Trunthung di Dusun Warangan. Salah satu tujuan penulisan artikel ini yaitu melakukan identifikasi mendalam tentang kearifan lokal dan kesenian tradisional yang dapat dijadikan sebagai konten dalam pembelajaran seni. Penelitian ini diawali dengan mengkaji beberapa literatur tentang kearifan lokal, pendidikan, dan seni tradisional. Selanjutnya, peneliti membuka beberapa dokumentasi yang sudah dilakukan pada tahun 2016 yang terkait dengan pertunjukan musik trunthung dan sajian musik trunthung dalam konteks pendidikan.

Lokasi penelitian di Dusun Warangan Kabupaten Magelang dan beberapa sekolah di Kota Magelang yaitu SMP 4 Magelang dan SMA 12 Kota Magelang. Lokasi ini dipilih karena musik Trunthung dihadirkan dalam ekstrakurikuler dan beberapa kali mengikuti event nasional di TMII Jakarta. Peran serta Handoko selaku seniman pengembang menjadi sumber wawancara utama dalam mengajarkan musik Trunthung hingga tersebar tidak hanya di Kabupaten Magelang, namun hingga Kota Magelang dan beberapa kota lainnya di Jawa Tengah. Sumber-sumber berupa data lapangan, wawancara, jurnal, dan buku menjadi data utama dalam pengkajian artikel ini. Hasil evaluasi dan sintesis dapat menjadi sumbangan pemikiran baru bagi penelitian tentang implikasi kearifan lokal dalam konteks pendidikan seni. 
Dalam mempermudah memahami kerangka berfikir dalam artikel ini, penulis membuat bagan berfikir tentang musik Trunthung sebagai manifestasi kearifan lokal dalam konteks pendidikan seni.

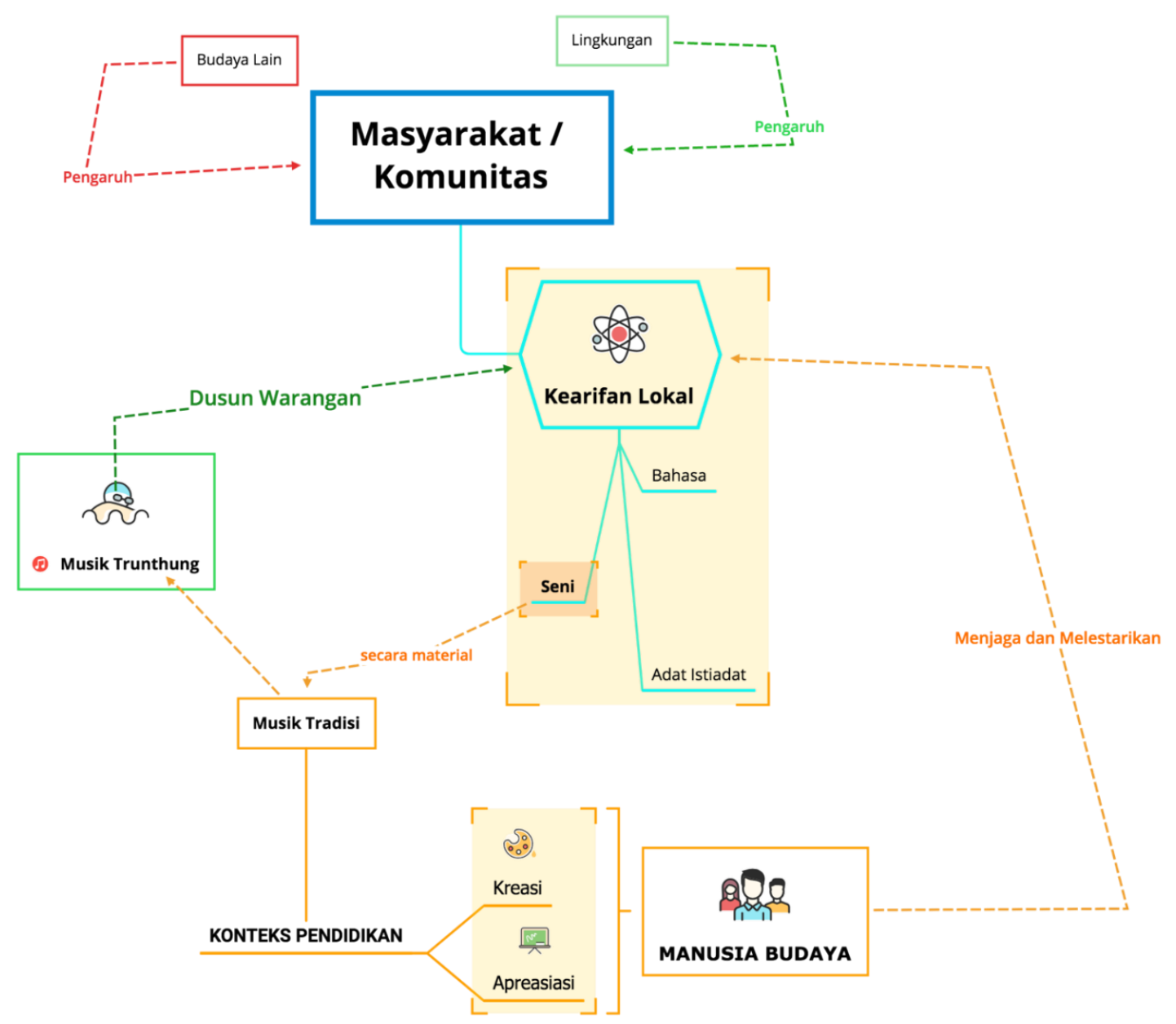

Gambar 1. Bagan Pemikiran Tentang Konsep Kearifan Lokal Musik Trunthung

Pola kehidupan di Dusun Warangan tidak terlepas dari pengaruh budaya luar dan kondisi lingkungan sekitar. Warangan merupakan dusun yang syarat seni dan tradisi, tidak heran jika masih banyak sekali ritual-ritual yang dilakukan masyarakat sebagai ucapan syukur terhadap hasil panen maupun ritual sebagai ucapan syukur atas sumber air yang melimpah.

Terlepas dari ritual yang dilakukan selalu berkaitan dengan kesenian tradisional yang disajikan sebagai salah satu syarat dalam ritual tersebut. Jika dikaji lebih lanjut, baik bahasa, seni maupun ada istiadat yang dilakukan masyarakat Warangan merupakan wujud dari kearifan lokal yang memiliki banyak unsur pembentuk dan identitas dari Dusun Warangan. 
Musik Trunthung adalah salah satu wujud kearifan lokal dalam sudut pandang kesenian. Handoko menyajikan musik Trunthung sebagai salah satu konten pembelajaran yang diberikan pada kegiatan ekstrakurikuler, baik di instansi maupun beberapa sekolah di Magelang. Melihat musik Trunthung sebagai konten pendidikan, maka di dalamnya terdapat dua kegiatan estetis yaitu kreasi dan apresiasi. Setelah beberapa rangkaian kegiatan tersebut dilakukan, harapannya dapat membentuk sebuah manusia budaya yang dapat melestarikan kesenian tradisional maupun kearifan lokal yang ada.

\section{Musik Trunthung dalam Konteks Sosial di Dusun Warangan}

Merton mendefinisikan fungsi sebagai konsekuensi-konsekuensi yang dapat diamati dan dibuat dengan tujuan adaptasi atau penyesuaian dari sistem tertentu. Adaptasi dan penyesuaian selalu bermakna positif bagi sistem. Itu sebabnya Merton kemudian mengenalkan konsep disfungsi untuk melihat adanya konsekuensi-konsekuensi yang justru merusak atau berakibat negatif pada sistem. Selain fungsi dan disfungsi, Merton juga mengenalkan konsep non-fungsi yaitu akibat-akibat yang tidak relevan dengan sistem (Ritzer \& Ryan, 2010, p. 253).

Konsep fungsi dan disfungsi berkaitan dengan akibat atau konsekuensi dari sesuatu. Konsekuensi itu dapat berupa sesuatu yang telah diantisipasi/ direncanakan (anticipated), dapat juga tidak diantisipasi/ direncanakan (unanticipated). Konsekuensi yang telah diantisipasi (anticipated consequences) dapat berupa sesuatu yang positif bagi sistem (fungsi manifes), dapat juga negatif bagi sistem (disfungsi manifes). Sementara konsekuensi yang tidak diantisipasi (unanticipated consequences) dapat positif (fungsi laten), dapat negatif (disfungsi laten), dapat juga sesuatu yang tidak relevan (non-fungsi) (Ritzer \& Ryan, 2010, p. 256).

Fungsi Ritual

Secara kontekstual musik Trunthung merupakan salah satu struktur yang terdapat dalam Tari Soreng, dimana Trunthung memiliki fungsi manifes sebagai salah satu alat musik pengiring yang mengatur tempo dan irama gerak. Jika dikaji lebih dalam, Tari Soreng adalah kesenian yang harus ada dalam pelaksanaan ritual Nyadaran Kali. Kehidupan masyarakat Dusun Warangan sangat bergantung pada sumber mata air Puyam. Sebagai daerah agraris, kehidupan masyarakat Warangan sangat erat hubungannya dengan 
ritual yang berkaitan dengan alam dan lingkungannya. Masyarakat Dusun Warangan masih menjunjung tinggi gotong royong, baik dalam hal pekerjaan, bertani, maupun kegiatan sosial seperti hajatan, kematian, peringatan hari-hari besar, dan upacara adat.

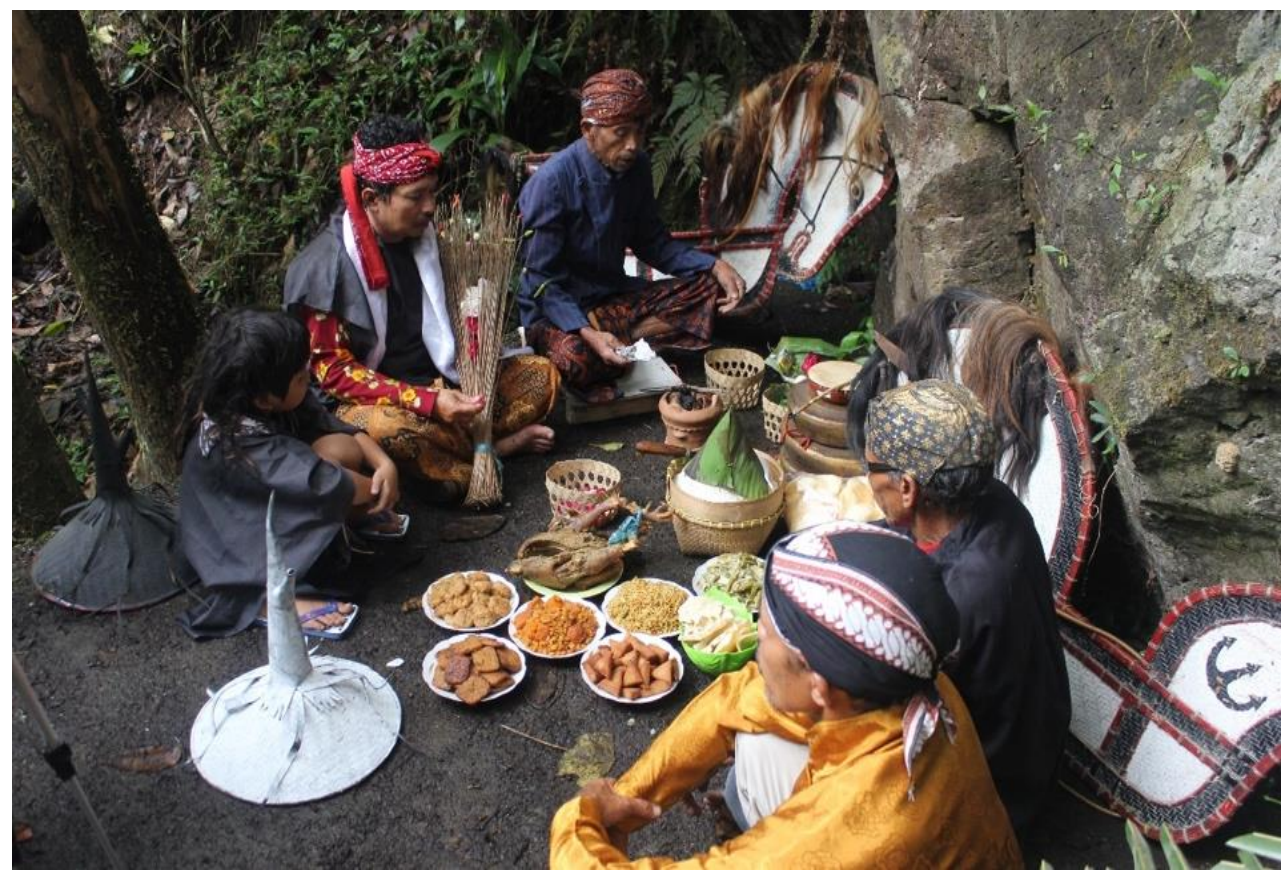

Gambar 2. Prosesi Nyadran Kali di Sumber Mata Air Puyam Dusun Warangan

(Dokumentasi: Sinaga, 2015)

Secara tidak langsung, pelaksanaan tradisi nyadran kali yang masih dilakukan juga memberikan kontribusi dalam hal konservasi budaya atau pelestarian seni tradisional yang ada di Dusun Warangan. Dalam hal ini dapat disebut juga sebagai fungsi laten yang dibuktikan dengan musik Trunthung tetap dimainkan selama upacara dilaksanakan setiap tahunnya. Hal tersebut seperti yang dikatakan oleh Sutanto Mendut dalam orasi budaya dalam Festival Lima Gunung Tahun 2014 di Dusun Warangan,

"Di sini, di Warangan, ada fenomena sosial yang unik. Sumber air dibagi untuk 3 dusun, ini sebenarnya bisa jadi konflik sosial, tetapi mereka menyelesaikan sendiri tanpa menggugat dan tanpa berkelahi. Makanya di sini ada tradisi Nyadran Kali tentang fenomena ini. Di Warangan juga ada tradisi Aum Panen, makanya beras tetap tersedia. Kebudayaan masyarakat melekat erat dalam aktivitas pertanian” (Hakim, 2015).

Salah satu nilai tradisi yang berkembang di Dusun Warangan merupakan perwujudan rasa syukur atas hasil pertanian yang melimpah, termasuk di dalamnya kesenian yang dipentaskan sebagai bagian dalam ritual maupun sebagai hiburan oleh masyarakat. 
Fungsi Hiburan

Perkembangan musik Trunthung dari pengiring menjadi sebuah pertunjukan musik yang memiliki nilai jual, tidak lepas dari peran Eko Sunyoto dan Handoko selaku seniman di Sanggar Seni Warangan. Handoko dalam hal ini berperan sebagai agen dalam mengajarkan kesenian tradisional kepada masyarakat Dusun Warangan yang dapat dilihat pada gambar 3 .

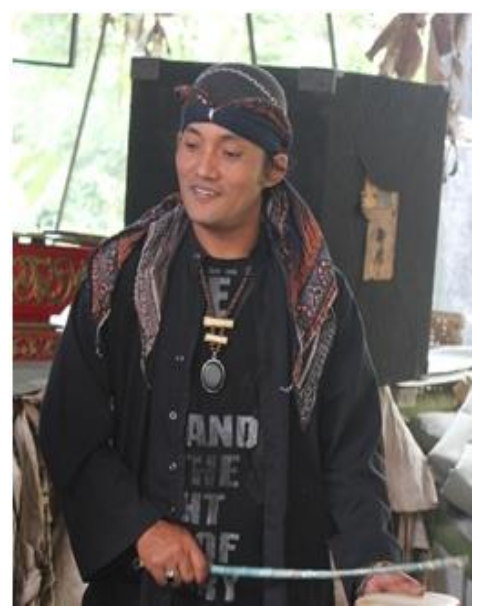

Gambar 3. Handoko Sebagai Ketua Sanggar Warangan Merbabu

Sanggar Warangan Merbabu berlokasi di kawasan Barat Gunung Merbabu yang dipimpin oleh Handoko. Festival Lima Gunung pertama kali pada tahun 2002 dan berhasil menghidupkan aktivitas berkesenian kelompok ini. Kelompok yang dikenal dengan kekhasan Topeng Ireng dan musik Trunthung telah banyak melakukan pementasan dan pelatihan kesenian di berbagai kalangan dan cukup aktif melakukan pementasan. Hal ini merupakan fungsi manifes dari musik Trunthung sebagai pengisi acara dan tentu saja merubah orientasi para pemain musik, yang pada awalnya hanya ingin melestarikan kesenian tradisional dalam lingkup yang kecil dan dengan adanya pementasan musik Trunthung dapat memberikan kesejahteraan secara finansial.

Sanggar Warangan Merbabu pada tahun 2002-2004 banyak melakukan pementasan musik Trunthung, di berbagai kota seperti Jakarta, Bandung, Yogyakarta, Semarang, dan Solo. Salah satu kegiatan rutin Sanggar Seni Warangan yaitu keikutsertaannya dalam Festival Lima Gunung yang diadakan setiap tahunnya dari tahun 2002 hingga terakhir pada tahun 2019 di Lereng Merapi.

Perkembangan musik Trunthung tidak lepas dari peran Komunitas Lima Gunung yang terbentuk pada tahun 2002 atas prakarsa budayawan Sutanto Mendut-pemilik Studio Mendut di Kecamatan Mungkid, Kabupaten Magelang. Seniman yang tergabung di 
dalamnya berasal dari kawasan lereng lima gunung dan perbukitan yang masuk wilayah Kabupaten Magelang yaitu Gunung Merapi, Merbabu, Sumbing, Andong, dan Perbukitan Menoreh (Rukmorini, 2018). Selain itu fungsi laten dapat dilihat ketika masing-masing perwakilan yang tergabung dalam Komunitas Lima Gunung mengekspresikan seni yang menjadi identitas atau ciri khas pada masing-masing sanggar seni tersebut. Musik Trunthung pada saat ini juga sudah termasuk dalam kesenian khas dari Kabupaten Magelang.

\section{Manifestasi Musik Trunthung sebagai Kearifan Lokal di Dusun Warangan}

Kearifan lokal terdiri dari 2 kata yaitu kearifan (wisdom) dan lokal (local). Local berarti setempat dan wisdom adalah kebijaksanaan. Dengan kata lain kearifan lokal—local wisdom - dapat dipahami sebagai gagasan-gagasan, nilai-nilai, atau pandangan-pandangan setempat yang bersifat bijaksana, penuh kearifan, bernilai baik, yang tertanam dan diikuti oleh anggota masyarakatnya (Antosa, 2014, p. 86). Menurut Sedyawati, kearifan lokal diartikan sebagai kearifan dalam kebudayaan tradisional suku-suku bangsa. Kearifan dalam arti luas tidak hanya berupa norma-norma dan nilai-nilai budaya, melainkan juga segala unsur gagasan, termasuk yang berimplikasi pada teknologi, penanganan kesehatan, dan estetika. Dengan pengertian tersebut maka yang termasuk sebagai penjabaran kearifan lokal adalah berbagai pola tindakan dan hasil budaya materialnya (Sedyawati, 2006, p. $382)$.

Pandangan-pandangan yang diakui secara intersubjektif akan membentuk suatu perilaku yang khas dari suatu kelompok. Salah satu implikasi dari kekhasan tersebut adalah kesenian tradisional atau dalam hal ini penulis akan menyoroti perihal musik tradisional yang berbeda-beda antara satu daerah dengan daerah lainnya.

Musik tradisional adalah kesenian — musik—yang tumbuh dan berkembang di suatu daerah tertentu yang diwariskan secara turun-temurun dari satu generasi kepada generasi berikutnya (Sinaga, 2016). Indonesia adalah salah satu negara dengan suku, etnis, bahasa, dan kesenian terbanyak di dunia. Seni sebagai salah satu unsur kebudayaan memiliki kontribusi yang besar dalam membentuk peradaban bangsa. Menurut Triyanto (2017a, p. 83) ketika orang berbicara peradaban, maka topik perbincangan tersebut akan mengarah kepada produk-produk kesenian yang memiliki kualitas unggulan yang berbeda-beda dari satu tempat dengan tempat lainnya. 
Pada konteks ini, penulis membawa contoh musik Trunthung yang berasal dari Dusun Warangan di Lereng Merbabu. Musik Trunthung adalah alat musik yang berfungsi sebagai pengiring Tari Soreng dalam sebuah ritual Nyadran Kali yang dilakukan oleh masyarakat lereng Merbabu (Sinaga, 2016). Hal tersebut menguatkan bahwa salah satu implikasi dari kepercayaan warga yang merupakan rasa syukur atas hasil alam yang melimpah menghasilkan sebuah seni yang turut serta menghiasi dalam sebuah proses kebudayaan masyarakat Warangan.

Dusun Warangan memiliki kesenian tradisional yang tumbuh dan berkembang sejak tahun 1960-an. Dari beberapa kesenian yang ada pada saat itu, berkembanglah kesenian Soreng sekitar tahun 1974 dan menjadi ‘pintu' bagi kesenian-kesenian lain untuk masuk di Dusun Warangan. Karena pesatnya perkembangan kesenian di Dusun Warangan, mendorong salah satu warga yaitu Eko Sunyoto berfikir untuk membentuk sebuah organisasi yang mewadahi seluruh kesenian-kesenian tersebut, yang dikenal dengan nama Sanggar Seni Warangan. Salah satu musik khas di Dusun Warangan adalah musik Trunthung.

Seiring berjalannya waktu, musik Trunthung yang pada awalnya hanya sebuah seni pelengkap dalam sebuah ritual tradisi berubah menjadi sebuah seni pertunjukan khas dari Kabupaten Magelang (Sinaga, 2016). Dalam konteks negara berkembang, upaya untuk memanfaatkan modal dan sumber kebudayaan melalui kesenian tradisional dan teknologi merupakan salah satu cara yang efisien bagi negara jika ingin membangun industri kebudayaan yang kokoh dan berdaya saing tinggi (Nurdyansyah, 2017; Rohidi, 2014, p. 1).

\section{Implikasi Musik Trunthung dalam Konteks Pendidikan Seni}

Menurut Triyanto (2017b, p. 36) kearifan lokal sebagai bentuk budaya diyakini memiliki nilai sejati dan membawa kebaikan di daerah setempat, keberadaannya harus dipertahankan. Dalam UU No. 20 tahun 2003 Pasal 13 ayat 1 dinyatakan bahwa jalur pendidikan terdiri dari pendidikan formal, non-formal, dan informal. Pendidikan formal merupakan pendidikan yang diselenggarakan di sekolah-sekolah pada umumnya. Jalur pendidikan ini mempunyai jenjang pendidikan yang jelas, mulai dari pendidikan dasar, pendidikan menengah, hingga pendidikan tinggi.

Pendidikan non-formal merupakan jalur pendidikan di luar pendidikan formal yang dapat dilaksanakan secara terstruktur dan berjenjang. Sebagai contoh yaitu berbagai kursus, diantaranya kursus musik dan sanggar seni-musik, tari maupun teater. Pendidikan 
non-formal berfungsi untuk mengembangkan potensi peserta didik dengan penekanan pada penguasaan pengetahuan dan keterampilan fungsional serta pengembangan sikap dan kepribadian profesional. Sedangkan pendidikan informal adalah jalur pendidikan keluarga dan lingkungan berbentuk kegiatan belajar secara mandiri yang dilakukan secara sadar dan bertanggung jawab. Namun, dalam hal ini hasil pendidikan informal diakui sama dengan pendidikan formal dan non-formal setelah peserta didik lulus ujian sesuai dengan standar nasional pendidikan.

Berdasarkan penjelasan di atas, tidak menutup kemungkinan bahwa musik Trunthung dalam konteks pendidikan seni dapat dijadikan sebagai konten pembelajaran, baik melalui pendidikan formal, non-formal, maupun informal. Salah satu contohnya adalah hadirnya musik Trunthung sebagai kegiatan ekstrakurikuler di beberapa sekolah menengah di Kabupaten Magelang.

Nilai-nilai ideal yang melekat dalam proses pendidikan seni erat berkaitan dengan proses pengalaman estetik (aesthetics experience), ketika individu bersentuhan dengan pengalaman kegiatan berkesenian dalam arti yang luas atau kompleks. Pengalaman estetik merupakan salah satu dimensi substansi dari tujuan pendidikan seni di sekolah umum, baik yang terdapat dalam sub-bidang kajian seni rupa, seni musik, seni tari, maupun seni sastra. Pengalaman estetik dapat diperoleh individu melalui serangkaian kegiatan berolah atau berkarya seni sesuai dengan sub-bidang kajian seni masing-masing dan juga melalui kegiatan apresiasi karya seni yang ada. Pengalaman estetik selalu dikaitkan dengan caracara untuk mengembangkan individu yang dirinci sebagai berikut:

1. Pengalaman estetik dan pengembangan potensi berfikir. Pengalaman estetik dalam pendidikan seni mempunyai korelasi yang positif bagi perkembangan individu pada segmentasi aspek berfikir individu. Pengalaman berolah seni dalam sub-bidang kajian seni apapun yang melibatkan proses komunikasi dengan lingkungannya dan dibantu dengan panca inderanya, sangat membantu bagi peletakan dasar-dasar penggunaan olah pikir - daya rasionalitas — individu yang bersangkutan secara filosofis dan mendasar.

2. Pengalaman estetik dan pengembangan ekspresi kreatif. Pengalaman estetik ditempatkan sebagai suatu aktivitas yang dapat mempertajam daya tangkap panca indera manusia. Selanjutnya berbagai informasi akan memperkaya muatan ingatan, yang pada gilirannya sewaktu-waktu dapat 'dipanggil' untuk diolah dalam memecahkan berbagai persoalan yang setiap saat diperlukan dalam kehidupan. Oleh karena itulah pendidikan estetika menjadi amat penting maknanya. 
Selain dalam ruang pendidikan formal, kehadiran musik Trunthung tidak dapat dipisahkan dari beberapa kegiatan budaya yang sering dilakukan di Kabupaten Magelang, salah satunya adalah Festival Lima Gunung.

\section{Aktivitas Kreatif dan Apresiatif dalam Ruang Budaya}

Musik Trunthung tercipta dan dipentaskan pertama kali pada Tahun 2002 dalam sebuah festival kerakyatan yaitu Festival Lima Gunung. Festival Lima Gunung adalah sebuah ikon bagi komunitas lima gunung. Festival yang diadakan sebagai ajang silaturahmi dengan keikhlasan, kesederhanaan, kejujuran, dan kebahagiaan yang dibangun secara bertahap dari tahun ke tahun. Festival Lima Gunung terus berlanjut dari tahun 2002 hingga yang terakhir pada tahun 2019.

Jika melihat dari aktivitasnya, seni memberikan ruang kepada para pelakunya untuk melakukan aktivitas kreatif dalam mengembangkan berbagai potensi artistiknya dalam menciptakan berbagai kesenian dengan muatan lokal sesuai dengan potensi alam dan nilainilai yang terkandung dalam kebiasaan masyarakatnya. Musik Trunthung merupakan musik yang dikembangkan oleh budayawan Sutanto Mendut dan Eko Sunyoto-seorang seniman dari Dusun Warangan. Selain sebagai ajang kreasi bagi para seniman gunung yang tergabung dalam komunitas lima gunung, Festival Lima Gunung juga merupakan ruang dialektika budaya yang terjadi antara budaya Lima Gunung dengan budaya yang berasal dari daearah lain, baik lokal maupun mancanegara.

Spirit konservatif juga terlihat dari aktivitas apresiasinya dengan cara merespon atas kesenian tradisional maupun kesenian dari budaya lain yang mengandung nilai-nilai dan keunikannya masing-masing. Apresiasi adalah suatu proses melihat, mendengar, menghayati, menilai, menjiwai, dan membandingkan atau menghargai suatu karya seni. Dalam kaitannya dengan kesenian, apresiasi berarti kegiatan mengartikan dan menyadari sepenuhnya seluk beluk karya seni serta menjadi sensitif terhadap gejala estetis dan artistik sehingga mampu menikmati dan menilai karya tersebut secara semestinya.

Melalui kegiatan apresiatif, kesenian tradisional mampu membentuk sikap toleran, memahami perbedaan, sikap peduli terhadap sesama, tenggang rasa, dan kerja sama. Hal ini menjadi modal yang sangat baik dalam membangun kesadaran budaya. Kesadaran budaya ini yang pada akhirnya akan menciptakan manusia berbudaya yang memiliki rasa untuk terus menjaga dan melestarikan kesenian, adat istiadat, norma tradisi maupun segala unsur kearifan lokal yang ada dalam masyarakat tersebut. 


\section{Kesimpulan}

Musik Trunthung merupakan manifestasi kearifan lokal yang berangkat dari sebuah masyarakat yang mayoritas berprofesi sebagai petani. Tidak heran jika nuansa kerakyatan sangat kental dalam setiap bunyi yang dihasilkan dari musik Trunthung. Kehadiran musik Trunthung sebagai kegiatan ekstrakurikuler di beberapa sekolah menengah di Kabupaten Magelang dapat dijadikan sebagai konten pembelajaran dalam ranah pendidikan formal, non-formal, maupun informal. Selain dalam ruang pendidikan formal, kehadiran musik Trunthung dalam perkembangannya menjadi sebuah pertunjukan baru yang diminati sejak kemunculan pertamannya di tahun 2002 pada acara Festival Lima Gunung. Musik Trunthung banyak sekali dikolaborasikan dengan beberapa alat musik lain maupun dengan genre modern lainnya.

Selain sebagai ajang kreasi bagi para seniman gunung yang tergabung dalam komunitas lima gunung, Festival Lima Gunung juga merupakan ruang dialektika budaya yang terjadi antara budaya Lima Gunung dengan budaya yang berasal dari daerah lain, baik lokal maupun mancanegara. Spirit konservatif juga terlihat dari aktivitas apresiasi terhadap kesenian tradisional lokal maupun kesenian dari budaya lain yang mengandung nilai-nilai dan keunikannya masing-masing.

\section{Kepustakaan}

Antosa, Z. (2014). Pendekatan kearifan lokal untuk meningkatkan kemampuan apresiasi seni mahasiswa pendidikan Guru Sekolah Dasar Fkip Universitas Riau. Primary: Jurnal Pendidikan Guru Sekolah Dasar, 3(2), 85-96.

Indonesia, K. K. (n.d.). Truntung. WARISAN BUDAYA TAKBENDA INDONESIA. Retrieved November 8, 2018, from https://warisanbudaya.kemdikbud.go.id/?newdetail\&detailCatat=4636

Nurdyansyah, N. (2017). Sumber Daya dalam Teknologi Pendidikan. Universitas Muhammadiyah Sidoarjo.

Rohidi, T. R. (2014). Pengembangan Media Pembelajaran Pendidikan Seni Budaya Berbasis Kearifan Lokal (Wayang Sebagai Sumber Gagasan). Imajinasi, VIII(1), 18.

Sedyawati, E. (2006). Budaya Indonesia: Kajian arkeologi, seni, dan sejarah. Divisi Buku Perguruan Tinggi, RajaGrafindo Persada.

Sinaga, Fajry Sub'haan Syah. (2016). Musik Trunthung Sebagai Media Ekspresi Masyarakat Warangan. Seminar Antar Bangsa, 161-174. https://doi.org/10.31227/osf.io/wc4vy 
Sinaga, Fajry Subhaan Syah. (2016). Transformasi Musik Trunthung dari Pengiring ke Pertunjukan di Dusun Warangan, Kecamatan Pakis, Kabupaten Magelang. Universitas Negeri Padang.

Sukarwo, W. (2017). Krisis Identitas Budaya: Studi Poskolonial pada Produk Desain Kontemporer. Jurnal Desain, 4(03), 311-324.

Triyanto, T. (2017a). Spirit Ideologis Pendidikan Seni. Cipta Prima Nusantara.

Triyanto, T. (2017b). ART EDUCATION BASED ON LOCAL WISDOM. Proceeding of International Conference on Art, Language, and Culture, 33-39. 